\title{
EFEKTIVITAS PENGEMBANGAN SEKTOR PARIWISATA JAWA TIMUR DENGAN PEDEKATAN HUMAN RESOURCES STRATEGY DAN MARKETING STRATEGY
}

\author{
Adya Hermawati ${ }^{1)}$, Choirul Anam ${ }^{2)}$, Suhermin $^{3)}$, Rahayu Puji Suci ${ }^{4}$ \\ 1,4) Program Studi Magister Manajemen, Universitas Widyagama Malang \\ 2) Program Studi Manajemen, Universitas Widyagama Malang \\ ${ }^{3)}$ Program Studi Manajemen, STIESIA Surabaya \\ Email: wati_wati38@yahoo.co.id
}

\begin{abstract}
Abstrak
Penelitian ini, kompilasi secara holistik terintegrasi dari konsep teori human resources strategy dengan konsep teori marketing strategy, melalui implementasi konsep dan aplikasi pemasaran pariwisata yang bertanggungjawab pada UMKM sektor pariwisata Jawa Timur. Tujuan dari penelitian ini pada dasarnya menetapkan bagaimana mencapai peningkatan kinerja SDM UMKM di sektor pariwisata dan strategi pemasaran pariwisata yang efektif di Jawa Timur. Metode penelitian ini menggunakan metode analisis Importance Performance Analysis (IPA). Populasi penelitian ini adalah sektor pariwisata UMKM di Jawa Timur. Berdasarkan hasil penelitian menggunakan proses Importance Performance Analysis diketahui nilai harapan dan kenyataan yang diterima oleh karyawan dan wisatawan memiliki di kuadran 3 dan 4, sedangkan pada selisih terbesar antara harapan dan kenyataan yang diterima memiliki angka interval 0.2 sampai dengan 0.69 disetiap masing-masing variabel.
\end{abstract}

Kata Kunci: Importance Performance Analysis (IPA), Strategi Pengembangan, UMKM, Pariwisata Jawa Timur

\begin{abstract}
This research, compiles the concept of human resource strategy that is integrated with the concept of marketing strategy theory, through the application of marketing concepts and applications that are responsible for the UMKM tourism sector in East Java. The purpose of this study when preparing a plan for achieving the improvement of SDM UMKM in the tourism sector and effective marketing strategies in East Java. This research method uses the Importance Performance Analysis (IPA) analysis method. The population of this study is the MSME sector in East Java. Based on the results of the study using the Performance Analysis process The Importance of Expectations and expectations received by employees and tourists has quadrants 3 and 4, while in the largest difference between expectations and reality that obtains an interval of 0.2 to 0.69 in each of each variable.
\end{abstract}

Keywords: Importance Performance Analysis (IPA), Development Strategy, UMKM, East Java Tourism.

\section{PENDAHULUAN}

Industri pariwisata sekarang menjadi salah satu faktor penting bagi kemajuan dunia. Sembilan persen dari Produk Domestik Bruto dunia dari negara-negara berasal dari sektor ini dan satu dari sebelas pekerja bekerja di sektor pariwisata (UNWTO, 2016). Kemajuan wisata yang luar biasa untuk kesejahteraan masyarakat dan memberikan tantangan pada saat yang sama bagi masyarakat setempat dan lingkungan sekitarnya. Kontribusi signifikan telah diberikan oleh sektor pariwisata Indonesia untuk kesejahteraan masyarakat melalui Produk Domestik Bruto Nasional sebesar 92,38\% (Kemenparekraf, 2016). Pada 2016 dan 2018, setelah minyak dan gas, batu bara dan minyak sawit (BPS, 2018). Secara khusus, di Jawa Timur, yang merupakan salah satu daerah otonom dengan tujuan wisata terkemuka di Indonesia, terus membangun daya saing pariwisata dalam rangka meningkatkan wilayah regional. 
UMKM adalah kontributor terbesar untuk PDB hingga saat ini. Oleh karena itu memberdayakan UMKM secara umum dan UMKM khusus sektor yang diperlukan karena mereka memiliki dampak yang signifikan pada peningkatan individu dan keseluruhan (PAD) di Jawa Timur. Pemerintah Jawa Timur membuka peluang bagi masyarakat untuk berpartisipasi dalam memaksimalkan tujuan wisata melalui pemberdayaan sektor pariwisata UMKM. Nilai lebih dari UMKM adalah sektor bisnis yang mampu bertahan dari krisis multidimensi 1998 dan krisis global 2008.

Poin penting dari program pembangunan nasional di bidang pariwisata membutuhkan kontribusi dan kerja keras semua aktor dalam berbagai kegiatan, sehingga perlu dilakukan terobosan. Antara lain, mengoptimalkan peran pelaku pariwisata di semua wilayah, memaksimalkan pemberdayaan organisasi pariwisata, mengembangkan dan mengelola dan memberdayakan sektor pariwisata UMKM menuju pasar bebas ASEAN (Suci et al., 2017). Selain itu, aspek SDM UMKM sektor pariwisata dan aspek pemasaran pariwisata yang bertanggung jawab memainkan peran utama dalam mencapai harmonisasi bisnis pariwisata dan pemberdayaan sektor pariwisata UMKM di Jawa Timur (Suhermin, 2015).

Salah satu cara untuk mengembangkan UMKM adalah mengembangkan, mengelola, dan memberdayakan UMKM di sektor pariwisata, yang diharapkan dapat memenuhi kebutuhan dan kepuasan wisatawan, sementara pada saat yang sama memberikan kontribusi positif untuk meningkatkan jumlah wisatawan, karena hal ini akan memiliki dampak signifikan pada kesejahteraan rakyat. Sekarang, UMKM di Jawa Timur di semua sektor dengan jumlah sumber daya manusia yang terus bertambah.

Sementara data riil menunjukan, jumlah wisatawan mancanegara maupun domestik ke Jawa Timur terpotret dalam kondisi instability pada capaian titik peningkatan yang belum signifikan. Hal ini dapat dilihat pada Grafik 1, tahun 2016 - 2018, jumlah wisatawan mancanegara yang datang ke jawa timur. Grafik 2, jumlah wisatawan domestik yang datang ke jawa timur tahun 2016 - 2018. Sehingga perlu aspek dan indikator pendongkrak wisatawan. Solusinya, strategi implementasi upaya pemberdayaan UMKM sektor pariwisata. Oleh karenanya pengembangan, pengelolaan dan pemberdayaan UMKM sektor pariwisata diharapkan dapat memenuhi kebutuhan dan kepuasan wisatawan, sekaligus memberikan kontribusi positif dalam meningkatkan jumlah wisatawan, karena lebih lanjut akan berdampak signifikansi pada kesejahteraan masyarakat. Sementara pada Tabel 1, analisis kuantitas UMKM di Jawa Timur pada semua sektor dengan jumlah SDM nya yang terus berkembang. Jumlah UMKM sebesar 6.825.931 dan jumlah SDM UMKM sebesar 11.117.439 di titik tahun 2018 . Lebih spesifik bahwa dari data tersebut kontribusi keberadaan UMKM di Jawa Timur, sebesar $45 \%$ adalah UMKM sektor pariwisata dengan jumlah SDM nya sebesar 4.550.200. Sehingga menjadi estimasi optimis UMKM sektor pariwisata sebagai kunci penggerak yang akan berkontribusi positif pada peningkatan jumlah wisatawan domestik maupun mancanegara.

Gambar Grafik 1 :

Jumlah Wisatawan Mancanegara Yang Datang Ke Jawa Timur Tahun 2016 - 2018

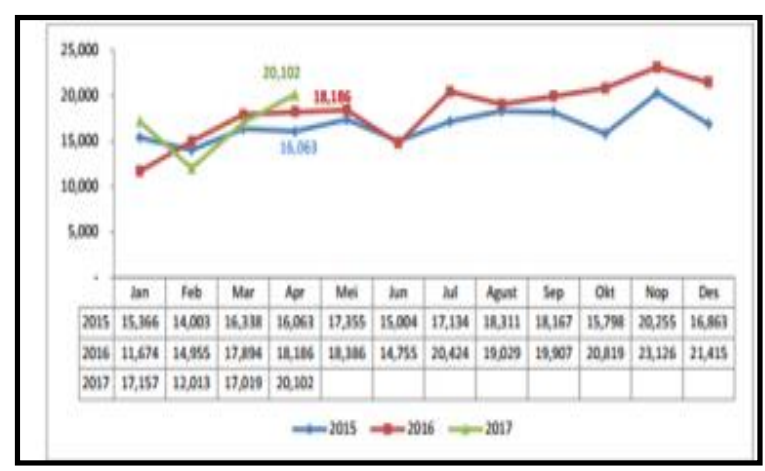




\section{Jumlah Wisatawan Domestik Yang Datang Ke Jawa Timur Tahun 2016 - 2018}

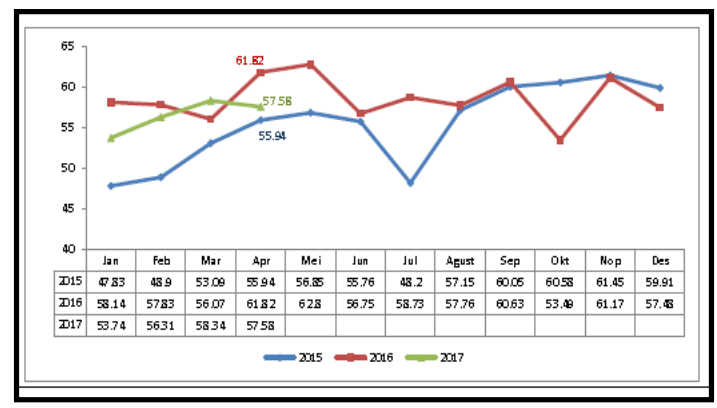

Hasil identifikasi, bahwa UMKM sektor pariwisata menjadi andalan pendapatan regional wilayah, sebagai antisipasi merosotnya pendapatan regional dari sektor lain. Titik penting program pembangunan nasional bidang pariwisata membutuhkan kontribusi dan kerja keras seluruh pelaku berbagai kegiatan, sehingga terobosan perlu dilakukan. Antara lain optimalisasi peran para pelaku pariwisata di seluruh daerah, maksimalisasi pemberdayaan organisasi kepariwisataan, pengembangan dan pengelolaan serta pemberdayaan UMKM sektor pariwisata menuju pasar bebas Asean (Suci et al., 2017).

Beberapa penelitian sebelumnya yang menguji hubungan antara kepemimpinan dan kinerja karyawan seperti (Holt \& Seki, 2012), bahwa efek langsung kepemimpinan transglobal berkontribusi terhadap kinerja karyawan untuk kinerja organisasi. Sebaliknya, penelitian Hayward, (2010) membuktikan bahwa kepemimpinan dalam organisasi tidak secara langsung memiliki pengaruh signifikan terhadap kinerja karyawan dan menemukan hubungan negatif antara kepemimpinan organisasi dan kinerja karyawan.

Dengan demikian, orisinalitas penelitian ini, kompilasi holistik terintegrasi dari konsep teori strategi sumber daya manusia dengan konsep teori strategi pemasaran, melalui penerapan konsep dan penerapan pemasaran pariwisata yang bertanggung jawab untuk sektor pariwisata UMKM di
Jawa Timur . Tentu saja, wisatawan perlu mendapatkan pemahaman yang baik tentang strategi pemasaran sehingga mereka dapat menjadi bagian dari mengendalikan daya saing pariwisata berkelanjutan (sustainability tourism competitiveness) di Jawa Timur. Selain itu, fokus pencapaian, dipandang perlu untuk mengembangkan model pemasaran pariwisata yang bertanggung jawab yang terintegrasi dari aspek kinerja SDM di sektor pariwisata terpadu, untuk mewujudkan daya saing pariwisata berkelanjutan di Jawa Timur. Temuan dari penelitian ini adalah selain fokus pengembangan ilmiah pada strategi sumber daya manusia dan strategi pemasaran.

\section{TINJAUAN PUSTAKA}

\section{Teori Manajemen Sumber Daya Manusia}

Teori Manajemen Sumber Daya Manusia. Menurut (Robbins \& Judge, 2006), (Tett \& Meyer, 1993) menyatakan jika kebutuhan karyawan terpenuhi, karyawan akan merasa puas, mampu bekerja secara optimal, lebih lanjut berkomitmen, implikasi pada kinerja individu yang optimal, kontribusi terhadap kinerja organisasi. Teori (Porter \& Lawler, 1968) menyatakan bahwa keterlibatan kerja menyebabkan kinerja seseorang meningkat. Hubungan positif antara keterlibatan kerja dan kinerja berdampak pada kinerja karyawan dan kinerja organisasi.

\section{Teori Manajemen Pemasaran}

Teori ini didukung oleh beberapa penelitian sebelumnya. (Sarkar et al., 2012) melakukan penelitian berjudul Pemasaran hijau dan Tantangan dan Peluang Pembangunan Berkelanjutan bahwa pemasaran hijau adalah sesuatu yang akan terus tumbuh baik dalam praktik maupun permintaan. Meler \& Ham, (2012) melakukan penelitian berjudul Pemasaran Hijau untuk Pariwisata Hijau, tentang pariwisata 
berkelanjutan, bentuk alternatif pariwisata yang pemasaran hijau dipandang sebagai strategi yang menunjukkan kerjasama antara pemasok dan penjual, mitra dan saingan, dalam rangka mencapai pembangunan ramah lingkungan di seluruh rantai nilai sebagai solusi terbaik untuk dua prinsip utama dalam memperoleh manfaat jangka panjang, dan kontribusi positif bagi lingkungan. Produk pariwisata berkelanjutan didefinisikan sebagai produk yang bertanggung jawab terhadap lingkungan, layak secara sosial dan ekonomis sehingga pengguna produk saat ini dapat memenuhi kebutuhan mereka tanpa mengurangi kebutuhan generasi mendatang (Dewi, 2011).

\section{METODE PENELITIAN}

Penelitian ini menggunakan Importance

Performance Analysis (IPA) untuk mendapatkan gambaran: tingkat kepuasan dan kepentingan SDM UMKM sektor pariwisata di Jawa Timur. Untuk kepentingan analisis dalam penelitian ini, maka jawaban itu dapat diberi skor sebagai berikut:

Tabel 1 Skor/nilai Tingkat Kepentingan dan Kepuasan

\begin{tabular}{|c|c|c|}
\hline Skor/Nilai & $\begin{array}{c}\text { Tingkat } \\
\text { Kepentingan }\end{array}$ & $\begin{array}{c}\text { Tingkat } \\
\text { Kepuasan }\end{array}$ \\
\hline $\mathbf{5}$ & Sangat penting & Sangat baik \\
\hline $\mathbf{4}$ & Penting & Baik \\
\hline $\mathbf{3}$ & Cukup penting & Cukup baik \\
\hline $\mathbf{2}$ & Tidak penting & Tidak baik \\
\hline $\mathbf{1}$ & $\begin{array}{c}\text { Sangat tidak } \\
\text { penting }\end{array}$ & $\begin{array}{c}\text { Sangat tidak } \\
\text { baik }\end{array}$ \\
\hline
\end{tabular}

Setelah dilakukan penghitungan dari masing-masing atribut yang dilakukan dengan rumus tersebut, selanjutnya akan diukur tingkat kepuasan konsumen dengan memasukkan ke dalam masing-masing kuadran yang terdapat pada diagram kartesius, yang akan ditunjukkan pada gambar berikut :

\begin{tabular}{|c|c|}
\hline $\begin{array}{c}\text { Kuadran A } \\
\text { Prioritas Utama }\end{array}$ & $\begin{array}{c}\text { Kuadran B } \\
\text { Pertahankan Prestasi }\end{array}$ \\
\hline Kuadran C & Kuadran D \\
Prioritas Rendah & Berlebihan \\
\hline
\end{tabular}

Gambar 1 Diagram Kartesius Importance Performance Analysis

Populasi dalam penelitian ini adalah 1) semua SDM UMKM di sektor pariwisata, 2) turis asing dan wisatawan domestik di Jawa Timur. Teknik pengambilan sampel dengan purposive sampling dari sektor pariwisata UMKM di Jawa Timur (di 16 kota potensi wisata). Penentuan ukuran sampel menggunakan kriteria minimum Model Struktural yaitu antara 100-200, dengan demikian menetapkan jumlah 200 sektor pariwisata UMKM dari 16 kota wisata potensial di Jawa Timur, sehingga satu sektor pariwisata UMKM diambil oleh 4 karyawan, dan 3 wisatawan. Studi ini melibatkan 1.400 orang.

Variabel Penelitian ini, yaitu Kepemimpinan Transglobal adalah kepemimpinan yang pengaruhnya melintasi batas budaya dan nasional, bersifat universal, dan memberikan kontribusi besar pada semangat manusia yang mengubah peradaban manusia. Menjadi layak oleh para pemimpin transglobal membuat kehidupan orang lain lebih menarik, lebih indah, lebih sejahtera, lebih bermartabat, dan lebih baik. Variabel Kualitas Kehidupan Kerja (QWL) yang mengukur persepsi karyawan bahwa mereka merasa secara fisik, aman secara psikologis, nyaman, relatif puas dan mampu tumbuh dan berkembang seperti manusia. Variabel Keterlibatan Kerja sebagai proses partisipatif yang menggunakan semua kapasitas karyawan dan dirancang untuk mendorong komitmen yang meningkat terhadap keberhasilan suatu organisasi. Variabel Perilaku kewarganegaraan organisasi (OCB) sebagai perilaku di tempat kerja yang sesuai dengan penilaian pribadi yang melebihi persyaratan kerja dasar seseorang. Perilaku karyawan "di atas dan 
di atas" deskripsi pekerjaan formal, dilakukan secara sukarela tanpa tekanan, tidak diakui secara formal dan tanpa sistem imbalan, tetapi berkontribusi pada. Serta, Kinerja SDM sebagai hasil yang dicapai oleh karyawan dalam pekerjaan mereka sesuai dengan kriteria tertentu yang berlaku untuk suatu pekerjaan, Selanjutnya variabel Pemasaran Bertanggung Jawab yang dapat diukur melalui beberapa indikator yaitu etika, nilai-nilai dan tanggung jawab sosial. Dan, variabel pariwisata keberlanjutan murni kompetitif yang diukur berdasarkan efektivitas, efisiensi dan ekonomi.

\section{HASIL PENELITIAN}

Berikut akan dijelaskan pengukuran IPA pada berbagai kota dengan keseluruhan variabel yang ditempatkan kedalam diagram Kartesius, bertujuan untuk

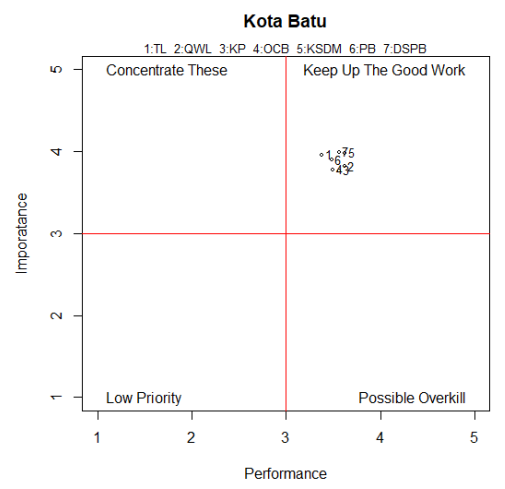

(a) melihat posisi setiap variabel yang ada dalam suatu konsep prioritas. Hasil pengukuran berbagai variabel didasarkan pada tingkat kepentingan wisatawan dan tingkat kinerja pihak UMKM, sehingga dapat membantu pihak UMKM untuk melakukan perbaikan-perbaikan pada variabel yang dianggap penting oleh wisatawan dan karyawan UMKM.

1) Kota Batu

Pengukuran keseluruhan variabel di Kota Batu dijabarkan kedalam diagram Kartesius yang tersaji pada Gambar berikut ini, yang memusat sumbu $\mathrm{X}$ dan $\mathrm{Y}$. Sumbu $\mathrm{X}$ merupakan nilai rataan tingkat kinerja dan sumbu $\mathrm{Y}$ merupakan nilai rataan kepentingan. Kedua sumbu tersebut membentuk dua garis tegak lurus yang saling berpotongan membagi diagram Kartesius menjadi empat kuadran.

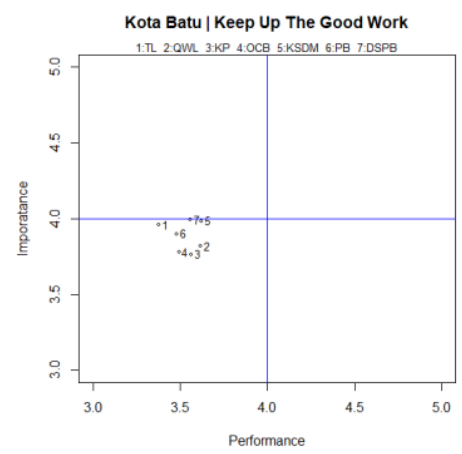

(b)

Gambar 1 (a) Diagram kartesius IPA Kota Batu (b) Diagram kartesius IPA kuadaran Keep up the Good Work Kota Batu

Diagram kartesius di atas menggambarkan harapan (importance) dan kenyataan (performance) yang diterima karyawan UMKM Sektor Pariwisata dan wisatawan, Selisih antara harapan dan kenyataan yang diterima oleh karyawan dan wisatawan untuk masing-masing variabel ditunjukkan oleh grafik batang berikut ini.

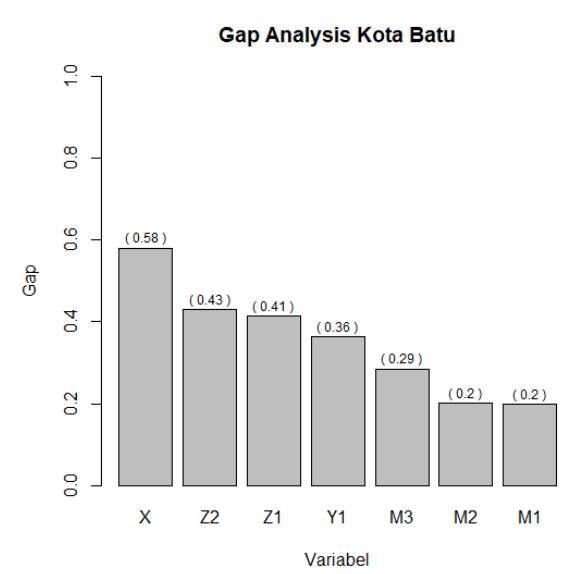

Gambar 2 Diagram Batang Gap Analysis Kota Batu 
Berdasarkan gambar di atas dapat dilihat bahwa variabel yang memiliki selisih terbesar antara harapan dan kenyataan yang diterima adalah variabel Transglobal Leadership, yaitu sebesar 0.58. Artinya, variabel utama yang perlu diperbaiki adalah Transglobal Leadership. Sementara itu, variabel yang memiliki selisih terkecil antara harapan dan kenyataan yang diterima adalah variabel Quality of Work Life dan Keterlibatan Pekerjaan, yaitu sebesar 0.2. Hal ini menunjukkan bahwa Quality of Work Life dan Keterlibatan Pekerjaan yang diterima karyawan

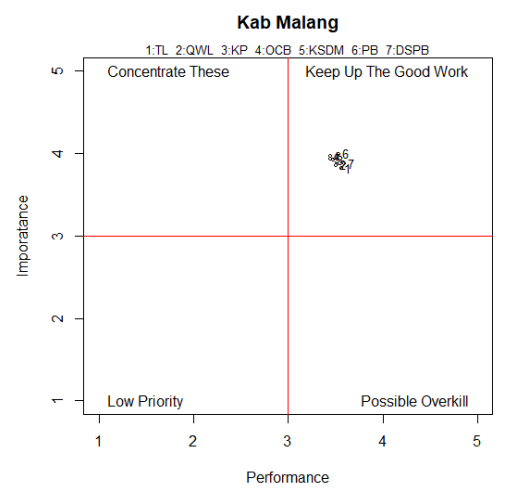

(a)
UMKM dan wisatawan yang ada di Kota Batu sudah sesuai dengan harapan.

2) Kabupaten Malang

Pengukuran keseluruhan variabel di Kabupaten Malang dijabarkan kedalam diagram Kartesius yang tersaji pada Gambar berikut ini, yang memusat sumbu $\mathrm{X}$ dan Y. Sumbu $\mathrm{X}$ merupakan nilai rataan tingkat kinerja dan sumbu $\mathrm{Y}$ merupakan nilai rataan kepentingan. Kedua sumbu tersebut membentuk dua garis tegak lurus yang saling berpotongan membagi diagram Kartesius menjadi empat kuadran.

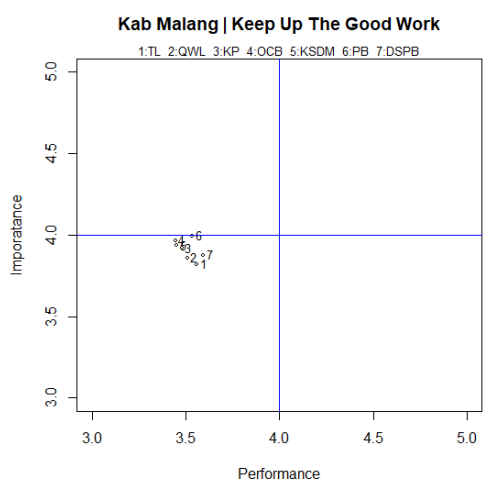

(b)

Gambar 2 (a) Diagram kartesius IPA Kabupaten Malang (b) Diagram kartesius IPA kuadaran Keep up the Good Work Kabupaten Malang

Diagram kartesius di atas menggambarkan harapan (importance) dan kenyataan (performance) yang diterima karyawan UMKM Sektor Pariwisata dan wisatawan Selisih antara harapan dan kenyataan yang diterima oleh karyawan dan wisatawan untuk masing-masing variabel ditunjukkan oleh grafik batang berikut ini.

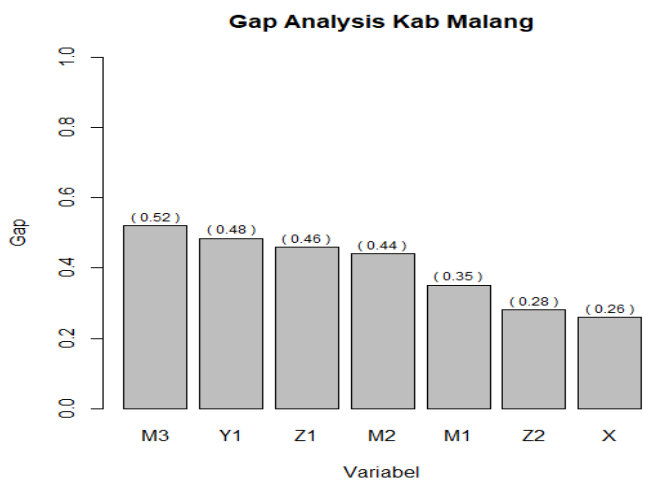

Gambar 3 Diagram Batang Gap Analysis Kabupaten Malang
Berdasarkan gambar di atas dapat dilihat bahwa variabel yang memiliki selisih terbesar antara harapan dan kenyataan yang diterima adalah variabel Organizational Citizenship Behaviour, yaitu sebesar 0.52. Artinya, variabel utama yang perlu diperbaiki adalah Organizational Citizenship Behaviour. Sementara itu, variabel yang memiliki selisih terkecil antara harapan dan kenyataan yang diterima adalah variabel Transgloblal Leadership, yaitu sebesar 0.26. Hal ini menunjukkan bahwa Transgloblal Leadership yang diterima karyawan UMKM dan wisatawan yang ada di Kabupaten Malang sudah sesuai dengan harapan.

\section{3) Kota Malang}

Pengukuran keseluruhan variabel di Kota Malang dijabarkan kedalam diagram Kartesius yang tersaji pada Gambar 
berikut ini, yang memusat sumbu $\mathrm{X}$ dan $\mathrm{Y}$. Sumbu $X$ merupakan nilai rataan tingkat kinerja dan sumbu $\mathrm{Y}$ merupakan nilai rataan kepentingan. Kedua sumbu tersebut membentuk dua garis tegak lurus yang

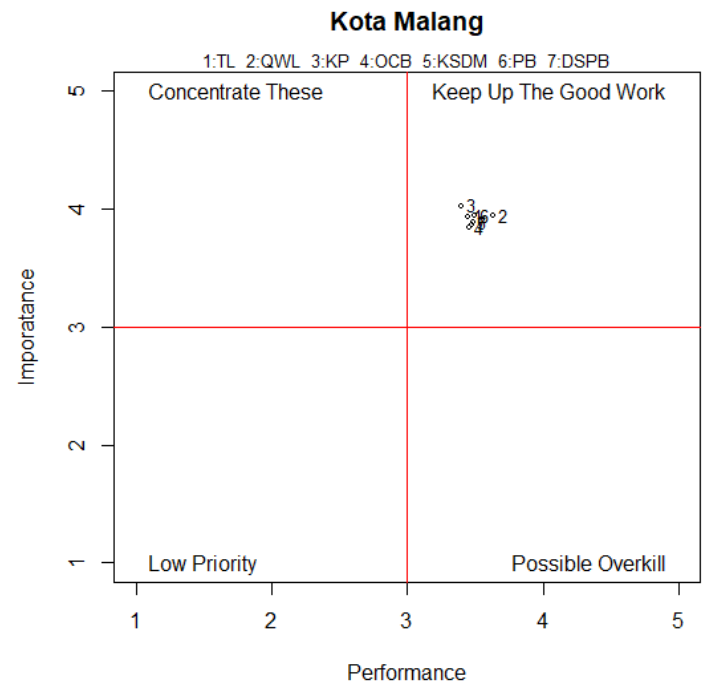

(a) saling berpotongan membagi diagram Kartesius menjadi empat kuadran.

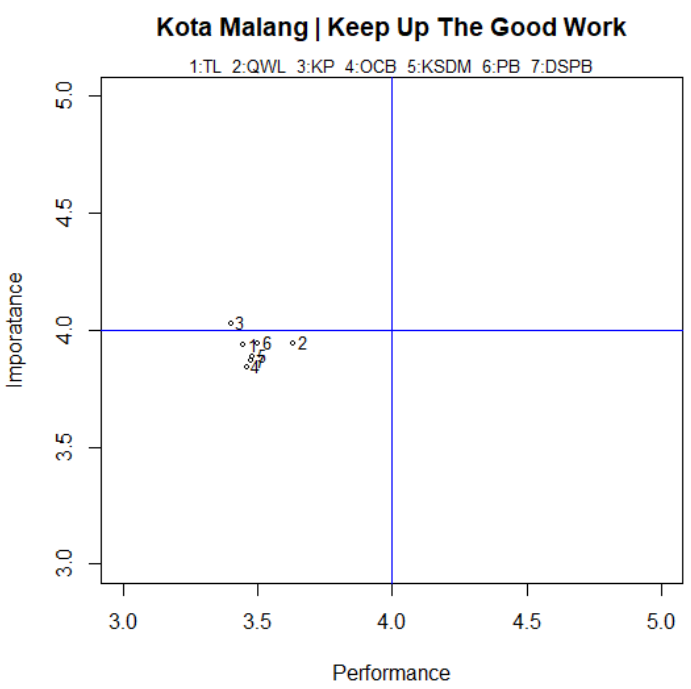

(b)

\section{Gambar 3 (a) Diagram kartesius IPA Kota Malang (b) Diagram kartesius IPA kuadaran Keep up the} Good Work Kota Malang

Diagram kartesius di atas menggambarkan harapan (importance) dan kenyataan (performance) yang diterima karyawan UMKM Sektor Pariwisata dan wisatawan di Kota Malang. Selisih antara harapan dan kenyataan yang diterima oleh karyawan dan wisatawan untuk masing-masing variabel ditunjukkan oleh grafik batang berikut ini.

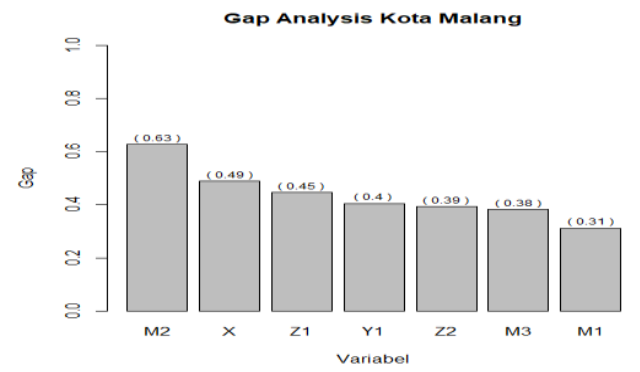

\section{Gambar 4 Diagram Batang Gap Analysis Kota Malang}

Berdasarkan gambar di atas dapat dilihat bahwa variabel yang memiliki selisih terbesar antara harapan dan kenyataan yang diterima adalah variabel Keterlibatan Pekerjaan, yaitu sebesar 0.63. Artinya, variabel utama yang perlu diperbaiki adalah Keterlibatan Pekerjaan. Sementara itu, variabel yang memiliki selisih terkecil antara harapan dan kenyataan yang diterima adalah variabel Quality of Work Life, yaitu sebesar 0.31. Hal ini menunjukkan bahwa Quality of Work Life yang diterima karyawan UMKM dan wisatawan yang ada di Kota Malang sudah sesuai dengan harapan.

4) Kota Pasuruan

Pengukuran keseluruhan variabel di Kota Pasuruan dijabarkan kedalam diagram Kartesius yang tersaji pada Gambar berikut ini, yang memusat sumbu $\mathrm{X}$ dan Y. Sumbu X merupakan nilai rataan tingkat kinerja dan sumbu Y merupakan nilai rataan kepentingan. Kedua sumbu tersebut membentuk dua garis tegak lurus yang saling berpotongan membagi diagram Kartesius menjadi empat kuadran. 


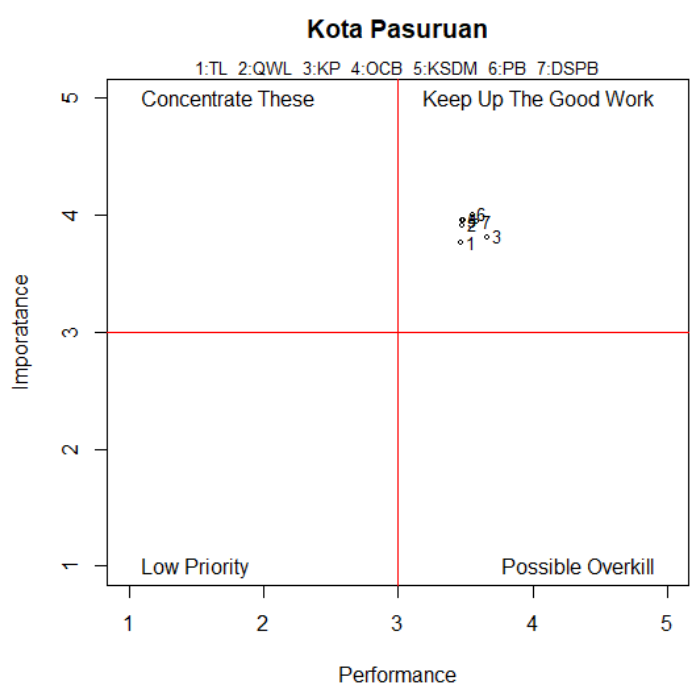

(a)

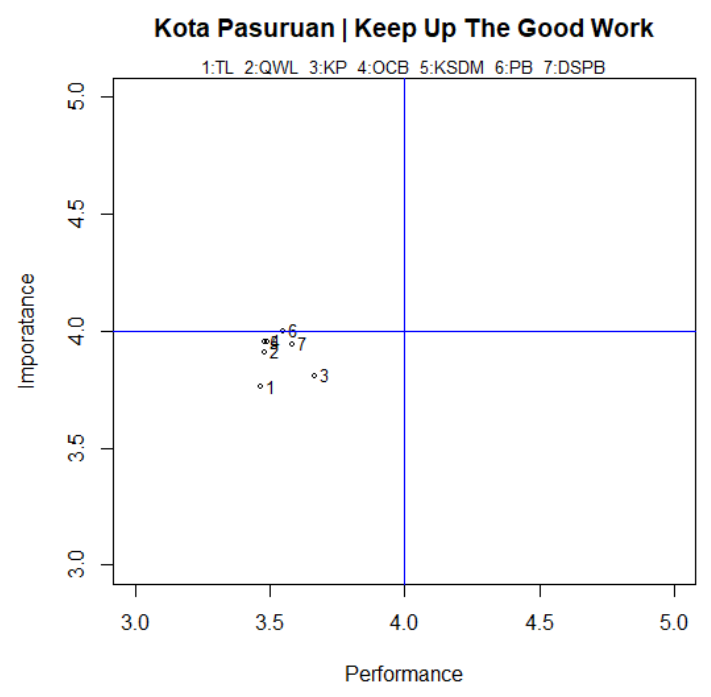

(b)

Gambar 4 (a) Diagram kartesius IPA Kota Pasuruan (b) Diagram kartesius IPA kuadaran Keep up the Good Work Kota Pasuruan

Diagram kartesius di atas menggambarkan harapan (importance) dan kenyataan (performance) yang diterima karyawan UMKM Sektor Pariwisata dan wisatawan di Kota Pasuruan. Selisih antara harapan dan kenyataan yang diterima oleh karyawan dan wisatawan untuk masing-masing variabel ditunjukkan oleh grafik batang berikut ini.

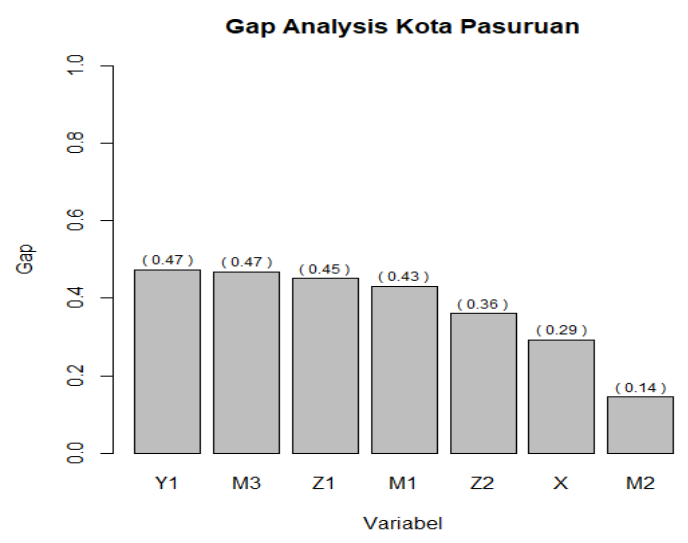

\section{Gambar 5 Diagram Batang Gap Analysis Kota Pasuruan}

Berdasarkan gambar di atas dapat dilihat bahwa variabel yang memiliki selisih terbesar antara harapan dan kenyataan yang diterima adalah variabel Kinerja Sumber Daya Manusia (Y1), yaitu sebesar 0.47. Artinya, variabel utama yang perlu diperbaiki adalah Kinerja Sumber Daya Manusia. Sementara itu, variabel yang memiliki selisih terkecil antara harapan dan kenyataan yang diterima adalah variabel Keterlibatan Pekerjaan, yaitu sebesar 0.14. Hal ini menunjukkan bahwa Keterlibatan Pekerjaan, yang diterima karyawan UMKM dan wisatawan yang ada di Kota Pasuruan sudah sesuai dengan harapan.

5) Kabupaten Pasuruan

Pengukuran keseluruhan variabel di Kabupaten Pasuruan dijabarkan kedalam diagram Kartesius yang tersaji pada Gambar berikut ini, yang memusat sumbu $X$ dan $Y$. Sumbu $X$ merupakan nilai rataan tingkat kinerja dan sumbu Y merupakan nilai rataan kepentingan. Kedua sumbu tersebut membentuk dua garis tegak lurus yang saling berpotongan membagi diagram Kartesius menjadi empat kuadran. 


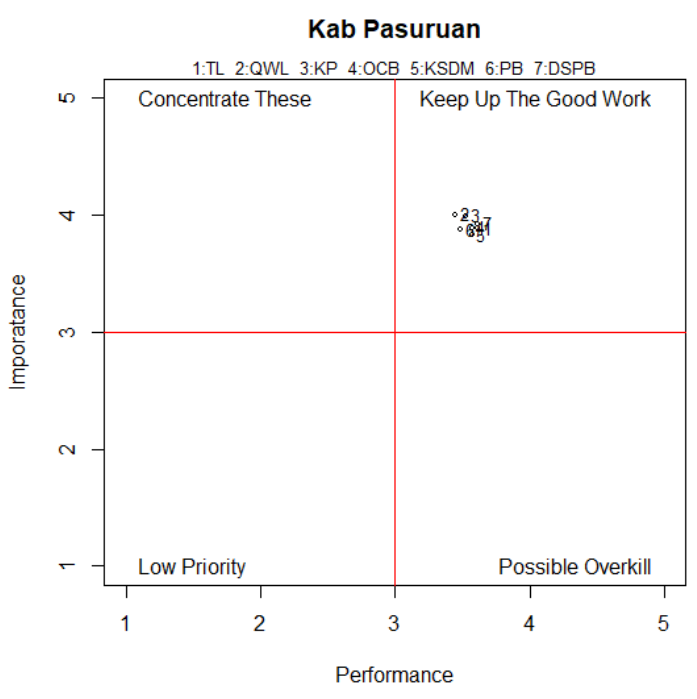

(a)

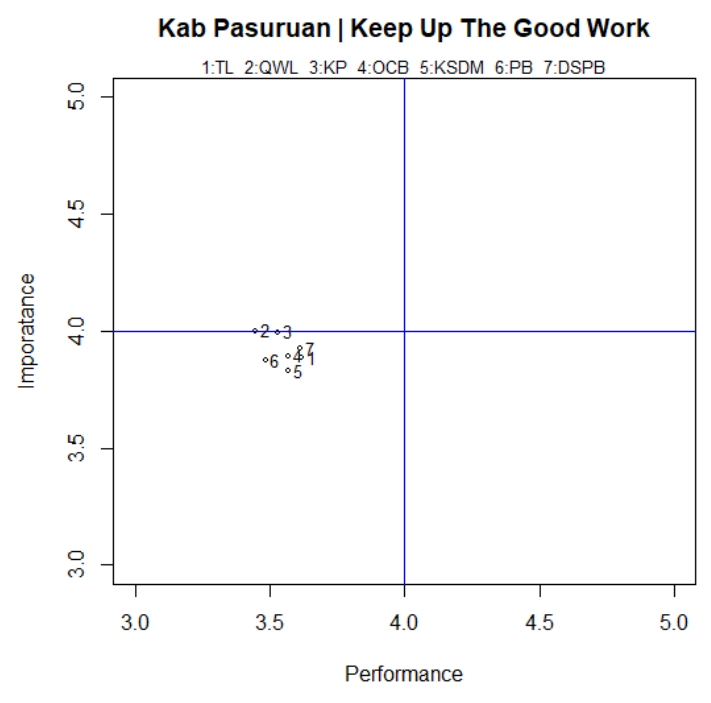

(b)

Gambar 5 (a) Diagram kartesius IPA Kabupaten Pasuruan (b) Diagram kartesius IPA kuadaran Keep up the Good Work Kabupaten Pasuruan

Diagram kartesius di atas menggambarkan harapan (importance) dan kenyataan (performance) yang diterima karyawan UMKM Sektor Pariwisata dan wisatawan di Kabupaten Pasuruan. Selisih antara harapan dan kenyataan yang diterima oleh karyawan dan wisatawan untuk masing-masing variabel ditunjukkan oleh grafik batang berikut ini.

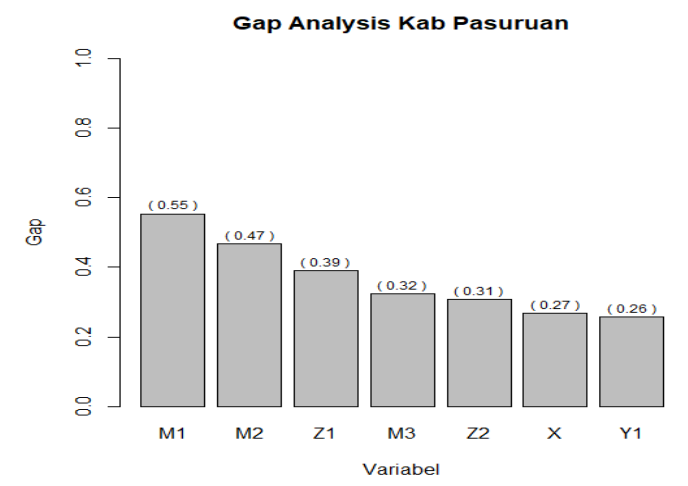

\section{Gambar 6 Diagram Batang Gap Analysis Kabupaten Pasuruan}

Berdasarkan gambar di atas dapat dilihat bahwa variabel yang memiliki selisih terbesar antara harapan dan kenyataan yang diterima adalah variabel Quality of Work Life, yaitu sebesar 0.55. Artinya, variabel utama yang perlu diperbaiki adalah Quality of Work Life. Sementara itu, variabel yang memiliki selisih terkecil antara harapan dan kenyataan yang diterima adalah variabel Kinerja Sumber Daya Manusia, yaitu sebesar 0.26. Hal ini menunjukkan bahwa Kinerja Sumber Daya Manusia, yang diterima karyawan UMKM dan wisatawan yang ada di Kabupaten Pasuruan sudah sesuai dengan harapan.

6) Kabupaten Sidoarjo

Pengukuran keseluruhan variabel di Kabupaten Sidoarjo dijabarkan kedalam diagram Kartesius yang tersaji pada Gambar berikut ini, yang memusat sumbu $X$ dan $Y$. Sumbu $X$ merupakan nilai rataan tingkat kinerja dan sumbu Y merupakan nilai rataan kepentingan. Kedua sumbu tersebut membentuk dua garis tegak lurus yang saling berpotongan membagi diagram Kartesius menjadi empat kuadran. 


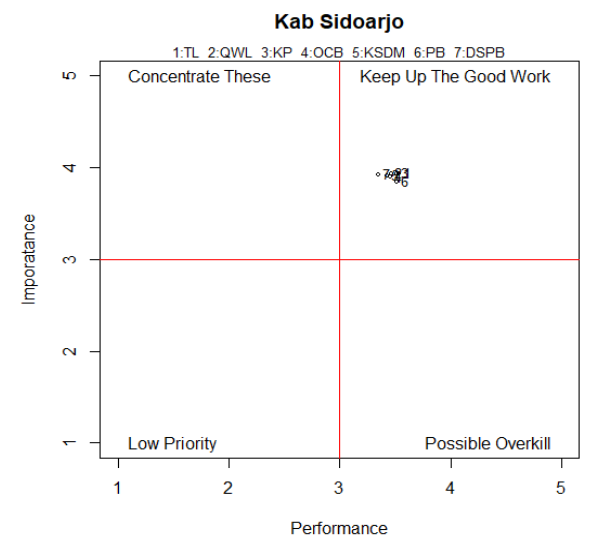

(a)

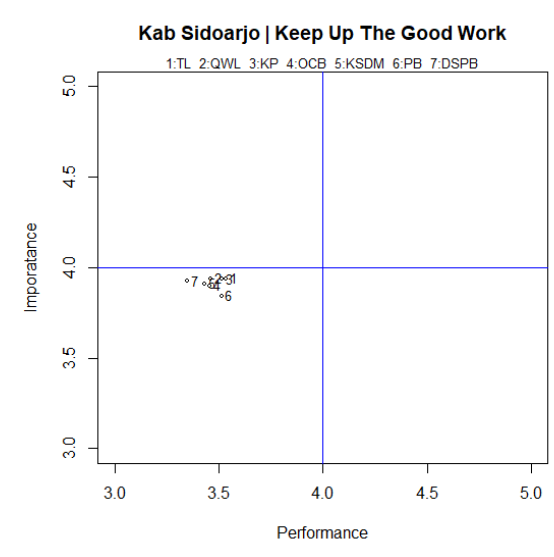

(b)

Gambar 6 (a) Diagram kartesius IPA Kabupaten Sidoarjo (b) Diagram kartesius IPA kuadaran Keep up the Good Work Kabupaten Sidoarjo

Diagram kartesius di atas menggambarkan harapan (importance) dan kenyataan (performance) yang diterima karyawan UMKM Sektor Pariwisata dan wisatawan di Kabupaten Sidoarjo. Selisih antara harapan dan kenyataan yang diterima oleh karyawan dan wisatawan untuk masing-masing variabel ditunjukkan oleh grafik batang berikut ini.

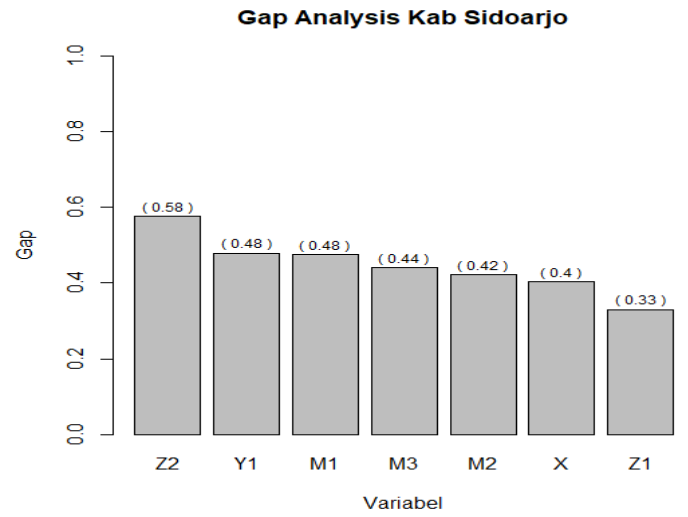

Gambar 7 Diagram Batang Gap Analysis Kabupaten Sidoarjo

Berdasarkan gambar di atas dapat dilihat bahwa variabel yang memiliki selisih terbesar antara harapan dan kenyataan yang diterima adalah variabel Daya Saing Pariwisata Berkelanjutan, yaitu sebesar 0.58. Artinya, variabel utama yang perlu diperbaiki adalah Daya Saing Pariwisata Berkelanjutan. Sementara itu, variabel yang memiliki selisih terkecil antara harapan dan kenyataan yang diterima adalah variabel Pemasaran Bertanggung Jawab, yaitu sebesar 0.33. Hal ini menunjukkan bahwa Pemasaran Bertanggung $J a w a b$, yang diterima karyawan UMKM dan wisatawan yang ada di Kabupaten Sidoarjo sudah sesuai dengan harapan.

7) Kabupaten Kediri

Pengukuran keseluruhan variabel di Kabupaten Kediri dijabarkan kedalam diagram Kartesius yang tersaji pada Gambar berikut ini, yang memusat sumbu $X$ dan $Y$. Sumbu $X$ merupakan nilai rataan tingkat kinerja dan sumbu Y merupakan nilai rataan kepentingan. Kedua sumbu tersebut membentuk dua garis tegak lurus yang saling berpotongan membagi diagram Kartesius menjadi empat kuadran. 


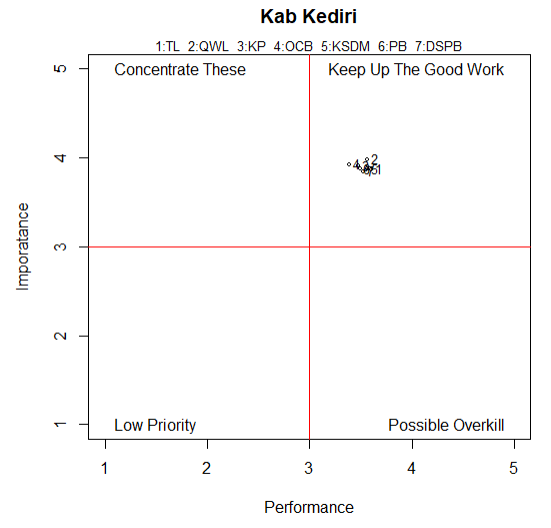

(a)

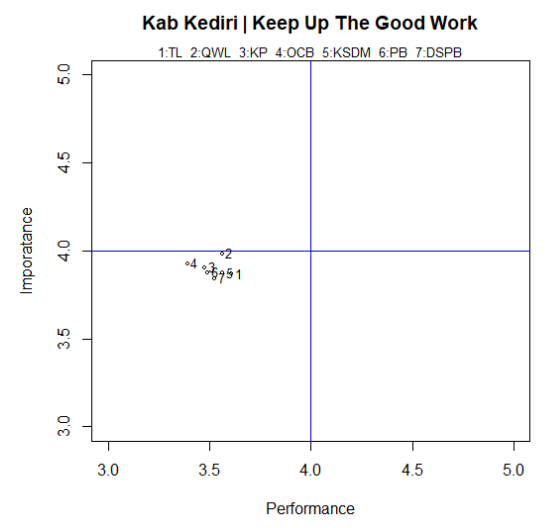

(b)

\section{Gambar 7 (a) Diagram kartesius IPA Kabupaten Kediri (b) Diagram kartesius IPA kuadaran Keep up the Good Work Kabupaten Kediri}

Diagram kartesius di atas menggambarkan harapan (importance) dan kenyataan (performance) yang diterima karyawan UMKM Sektor Pariwisata dan wisatawan di Kabupaten Kediri. Selisih antara harapan dan kenyataan yang diterima oleh karyawan dan wisatawan untuk masing-masing variabel ditunjukkan oleh grafik batang berikut ini.

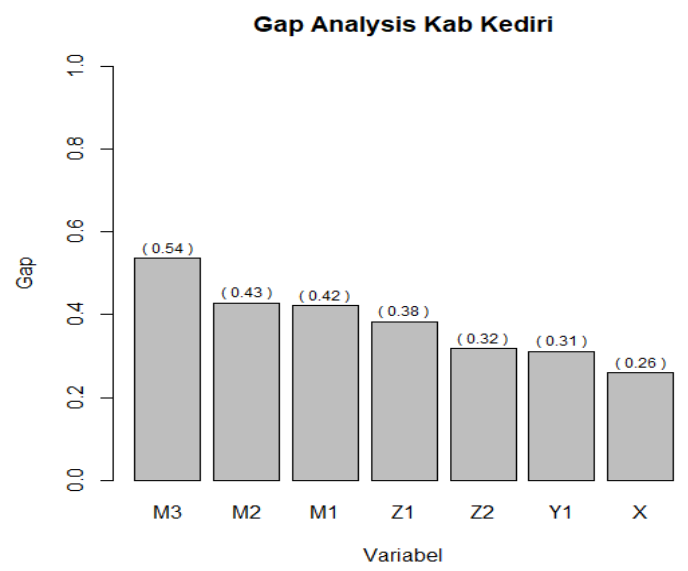

\section{Gambar 8 Diagram Batang Gap Analysis Kabupaten Kediri}

Berdasarkan gambar di atas dapat dilihat bahwa variabel yang memiliki selisih terbesar antara harapan dan kenyataan yang diterima adalah variabel Organizational Citizenship Behaviour, yaitu sebesar 0.54. Artinya, variabel utama yang perlu diperbaiki adalah Organizational Citizenship Behaviour. Sementara itu, variabel yang memiliki selisih terkecil antara harapan dan kenyataan yang diterima adalah variabel Transglobal Leadershi, yaitu sebesar 0.26. Hal ini menunjukkan bahwa Transglobal Leadership, yang diterima karyawan UMKM dan wisatawan yang ada di Kabupaten Kediri sudah sesuai dengan harapan.

8) Kota Kediri

Pengukuran keseluruhan variabel di Kota Kediri dijabarkan kedalam diagram Kartesius yang tersaji pada Gambar berikut ini, yang memusat sumbu $\mathrm{X}$ dan $\mathrm{Y}$. Sumbu $\mathrm{X}$ merupakan nilai rataan tingkat kinerja dan sumbu Y merupakan nilai rataan kepentingan. Kedua sumbu tersebut membentuk dua garis tegak lurus yang saling berpotongan membagi diagram Kartesius menjadi empat kuadran. 


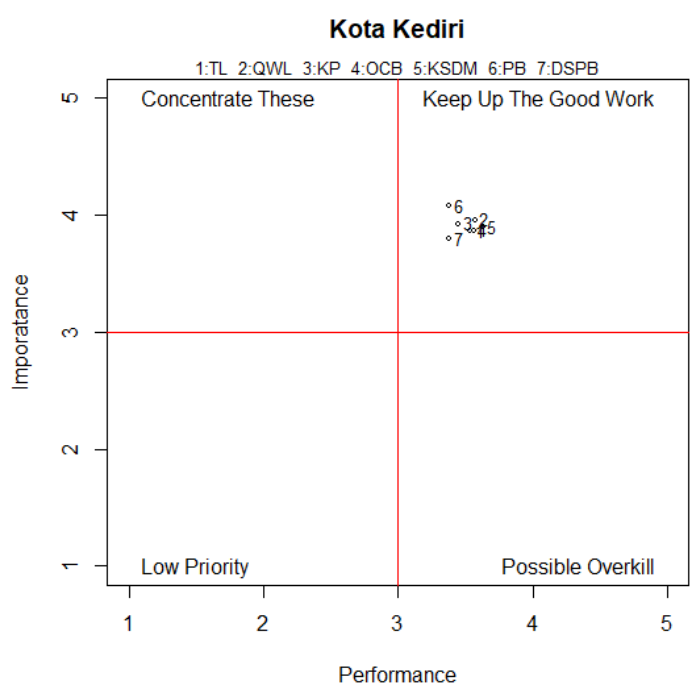

(a)

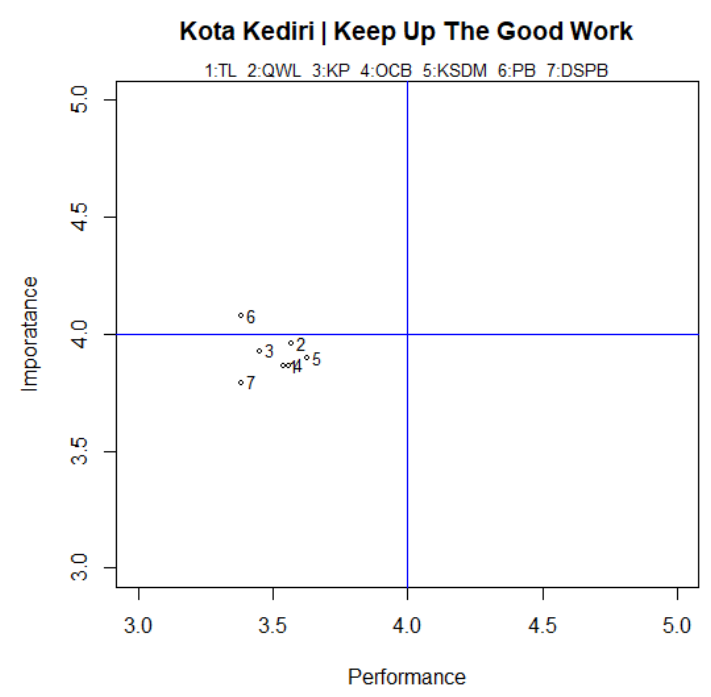

(b)

\section{Gambar 8 (a) Diagram kartesius IPA Kota Kediri (b) Diagram kartesius IPA kuadaran Keep up the Good Work Kota Kediri}

Diagram kartesius di atas menggambarkan harapan (importance) dan kenyataan (performance) yang diterima karyawan UMKM Sektor Pariwisata dan wisatawan di Kota Kediri. Selisih antara harapan dan kenyataan yang diterima oleh karyawan dan wisatawan untuk masing-masing variabel ditunjukkan oleh grafik batang berikut ini.

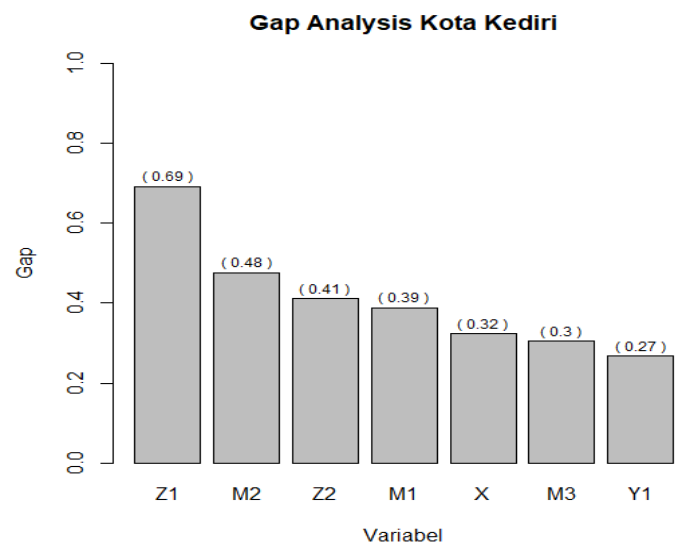

Gambar 9 Diagram Batang Gap Analysis Kota Kediri

Berdasarkan gambar di atas dapat dilihat bahwa variabel yang memiliki selisih terbesar antara harapan dan kenyataan yang diterima adalah variabel Pemasaran Bertanggung Jawab, yaitu sebesar 0.69. Artinya, variabel utama yang perlu diperbaiki adalah Pemasaran Bertanggung Jawab. Sementara itu, variabel yang memiliki selisih terkecil antara harapan dan kenyataan yang diterima adalah variabel Kinerja Sumber Daya Manusia, yaitu sebesar 0.27. Hal ini menunjukkan bahwa Kinerja Sumber Daya Manusia, yang diterima karyawan UMKM dan wisatawan yang ada di Kota Kediri sudah sesuai dengan harapan.

9) Kabupaten Blitar

Pengukuran keseluruhan variabel di Kabupaten Blitar dijabarkan kedalam diagram Kartesius yang tersaji pada Gambar berikut ini, yang memusat sumbu $\mathrm{X}$ dan $\mathrm{Y}$. Sumbu $\mathrm{X}$ merupakan nilai rataan tingkat kinerja dan sumbu Y merupakan nilai rataan kepentingan. Kedua sumbu tersebut membentuk dua garis tegak lurus yang saling berpotongan membagi diagram Kartesius menjadi empat kuadran. 


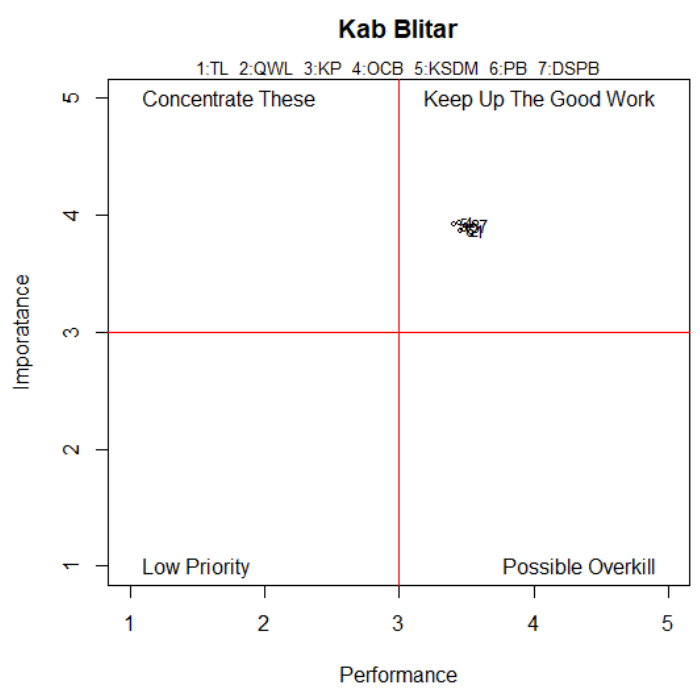

(a)

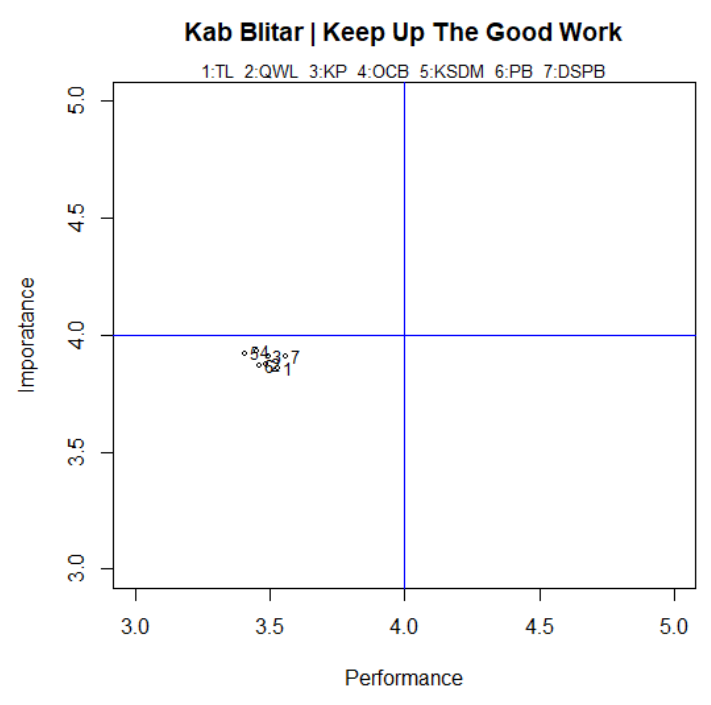

(b)

\section{Gambar 9 (a) Diagram kartesius IPA Kabupaten Blitar (b) Diagram kartesius IPA kuadaran Keep up the Good Work Kabupaten Blitar}

Diagram kartesius di atas menggambarkan harapan (importance) dan kenyataan (performance) yang diterima karyawan UMKM Sektor Pariwisata dan wisatawan di Kabupaten Blitar. Selisih antara harapan dan kenyataan yang diterima oleh karyawan dan wisatawan untuk masing-masing variabel ditunjukkan oleh grafik batang berikut ini.

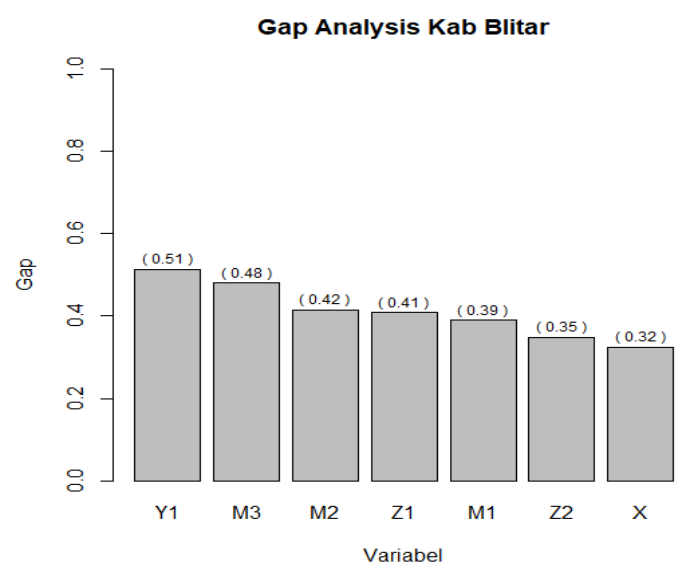

\section{Gambar 10 Diagram Batang Gap Analysis Kabupaten Blitar}

Berdasarkan gambar di atas dapat dilihat bahwa variabel yang memiliki selisih terbesar antara harapan dan kenyataan yang diterima adalah variabel Kinerja Sumber Daya Manusia, yaitu sebesar 0.51. Artinya, variabel utama yang perlu diperbaiki adalah Kinerja Sumber Daya Manusia. Sementara itu, variabel yang memiliki selisih terkecil antara harapan dan kenyataan yang diterima adalah variabel Transglobal Leadership, yaitu sebesar 0.32. Hal ini menunjukkan bahwa Transglobal Leadership, yang diterima karyawan UMKM dan wisatawan yang ada di Kabupaten Blitar sudah sesuai dengan harapan.

10) Kota Blitar

Pengukuran keseluruhan variabel di Kota Blitar dijabarkan kedalam diagram Kartesius yang tersaji pada Gambar berikut ini, yang memusat sumbu $\mathrm{X}$ dan $\mathrm{Y}$. Sumbu $\mathrm{X}$ merupakan nilai rataan tingkat kinerja dan sumbu Y merupakan nilai rataan kepentingan. Kedua sumbu tersebut membentuk dua garis tegak lurus yang saling berpotongan membagi diagram Kartesius menjadi empat kuadran. 


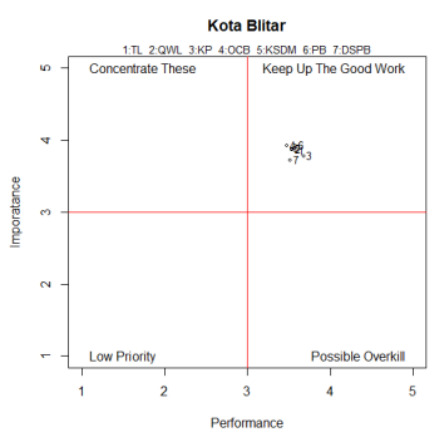

(a)

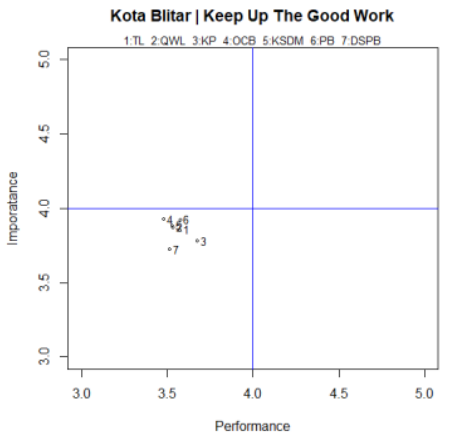

(b)

\section{Gambar 10 (a) Diagram kartesius IPA Kota Blitar (b) Diagram kartesius IPA kuadaran Keep up the Good Work Kota Blitar}

Diagram kartesius di atas menggambarkan harapan (importance) dan kenyataan (performance) yang diterima karyawan UMKM Sektor Pariwisata dan wisatawan di Kota Blitar. Selisih antara harapan dan kenyataan yang diterima oleh karyawan dan wisatawan untuk masing-masing variabel ditunjukkan oleh grafik batang berikut ini.

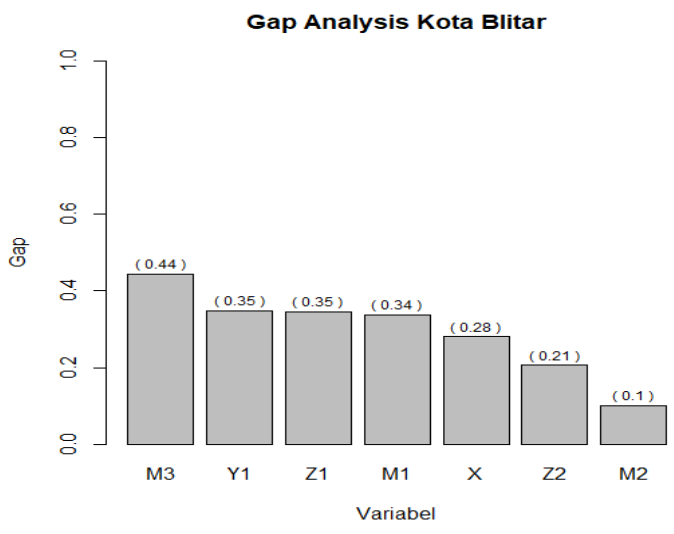

\section{Gambar 11 Diagram Batang Gap Analysis Kota Blitar}

Berdasarkan gambar di atas dapat dilihat bahwa variabel yang memiliki selisih terbesar antara harapan dan kenyataan yang diterima adalah variabel Organizational Citizenship Behaviour, yaitu sebesar 0.44. Artinya, variabel utama yang perlu diperbaiki adalah Organizational Citizenship Behaviour. Sementara itu, variabel yang memiliki selisih terkecil antara harapan dan kenyataan yang diterima adalah variabel Keterlibatan Pekerjaan, yaitu sebesar 0.1.
Hal ini menunjukkan bahwa Keterlibatan Pekerjaan, yang diterima karyawan UMKM dan wisatawan yang ada di Kota Blitar sudah sesuai dengan harapan.

\section{Pembahasan}

Tujuan dari penelitian ini pada dasarnya menetapkan bagaimana mencapai peningkatan kinerja SDM UMKM di sektor pariwisata dan strategi pemasaran pariwisata yang efektif di Jawa Timur. SDM adalah kebutuhan karyawan yang terpenuhi, karyawan yang merasa puas, dan karyawan yang mampu bekerja secara optimal guna meningkatkan komitmen individu/organisasi (kelompok UMKM) terhadap kinerja organisasi ( Robbins \& Judge, 2006; Tett \& Meyer, 1993; Bernadin \& Russel, 1993. Hal ini dapat diartikan bahwa setiap individu/kelompok harus memiliki komitmen guna mendiptakan kinerja usaha (UMKM) dengan melibatkan beberapa individu/kelompok sehingga mampu berdampak pada OCB di UMKM tersebut (Hermawati \& Mas, 2016: Alotaibi, 2001; Soumendu \& Arup, 2007).

Merujuk pada teori pariwisata (marketing) diketahui bahwa pariwisata berkelanjutan, bentuk alternatif pariwisata yang pemasaran hijau dipandang sebagai strategi yang menunjukkan kerjasama antara pemasok dan penjual, mitra dan saingan, dalam rangka mencapai pembangunan ramah lingkungan di 
seluruh rantai nilai sebagai solusi terbaik untuk dua prinsip utama dalam memperoleh manfaat jangka panjang, dan kontribusi positif bagi lingkungan. Produk pariwisata berkelanjutan didefinisikan sebagai produk yang bertanggung jawab terhadap lingkungan, layak secara sosial dan ekonomis sehingga pengguna produk saat ini dapat memenuhi kebutuhan mereka tanpa mengurangi kebutuhan generasi mendatang (Dewi, 2011; Meler \& Ham, 2012; Sarkar et al., 2012). Hal ini ditunjukkan dari hasil analisis dengan Importance Performance Analysis (IPA) untuk mendapatkan gambaran: tingkat kepuasan dan kepentingan SDM UMKM sektor pariwisata di Jawa Timur.

Kota Batu diketahui bahwa Transglobal Leadership, Quality of Work Life, Keterlibatan Pekerjaan, Organizational Citizenship Behavior, Kinerja Sumber Daya Manusia, Pemasaran Bertanggungjawab, dan Daya Saing Pariwisata Berkelanjutan berada pada kuadran II (Keep up the Good Work). Hal ini menunjukkan bahwa harapan dan kenyatan yang diterima karyawan dan wisatawan atas seluruh variabel samasama tinggi. Secara spesifik, nilai harapan dan kenyataan yang diterima oleh karyawan dan wisatawan atas seluruh variabel berkisar antara 3 hingga 4 . di Kabupaten Malang. Berdasarkan diagram tersebut dapat diketahui bahwa Transglobal Leadership, Quality of Work Life, Keterlibatan Pekerjaan, Organizational Citizenship Behavior, Kinerja Sumber Daya Manusia, Pemasaran Bertanggungjawab, dan Daya Saing Pariwisata Berkelanjutan berada pada kuadran II (Keep up the Good Work). Hal ini menunjukkan bahwa harapan dan kenyatan yang diterima karyawan dan wisatawan atas seluruh variabel samasama tinggi. Secara spesifik, nilai harapan dan kenyataan yang diterima oleh karyawan dan wisatawan atas seluruh variabel berkisar antara 3 hingga 4 . Kota Malang dapat diketahui bahwa
Transglobal Leadership, Quality of Work Life, Keterlibatan Pekerjaan, Organizational Citizenship Behavior, Kinerja Sumber Daya Manusia, Pemasaran Bertanggungjawab, dan Daya Saing Pariwisata Berkelanjutan berada pada kuadran II (Keep up the Good Work). Hal ini menunjukkan bahwa harapan dan kenyatan yang diterima karyawan dan wisatawan atas seluruh variabel samasama tinggi. Secara spesifik, nilai harapan dan kenyataan yang diterima oleh karyawan dan wisatawan atas seluruh variabel berkisar antara 3 hingga 4.2.

Kota Pasuruan diketahui bahwa Transglobal Leadership, Quality of Work Life, Keterlibatan Pekerjaan, Organizational Citizenship Behavior, Kinerja Sumber Daya Manusia, Pemasaran Bertanggungjawab, dan Daya Saing Pariwisata Berkelanjutan berada pada kuadran II (Keep up the Good Work). Hal ini menunjukkan bahwa harapan dan kenyatan yang diterima karyawan dan wisatawan atas seluruh variabel samasama tinggi. Secara spesifik, nilai harapan dan kenyataan yang diterima oleh karyawan dan wisatawan atas seluruh variabel berkisar antara 3 hingga 4 . Kabupaten Pasuruan dapat diketahui bahwa Transglobal Leadership (X), Quality of Work Life, Keterlibatan Pekerjaan, Organizational Citizenship Behavior, Kinerja Sumber Daya Manusia, Pemasaran Bertanggungjawab, dan Daya Saing Pariwisata Berkelanjutan berada pada kuadran II (Keep up the Good Work). Hal ini menunjukkan bahwa harapan dan kenyatan yang diterima karyawan dan wisatawan atas seluruh variabel samasama tinggi. Secara spesifik, nilai harapan dan kenyataan yang diterima oleh karyawan dan wisatawan atas seluruh variabel berkisar antara 3 hingga 4 .

Kota Sidoarjo dapat diketahui bahwa Transglobal Leadership, Quality of Work Life, Keterlibatan Pekerjaan, Organizational Citizenship Behavior, Kinerja Sumber Daya Manusia, Pemasaran 
Bertanggungjawab, dan Daya Saing Pariwisata Berkelanjutan berada pada kuadran II (Keep up the Good Work). Hal ini menunjukkan bahwa harapan dan kenyatan yang diterima karyawan dan wisatawan atas seluruh variabel samasama tinggi. Secara spesifik, nilai harapan dan kenyataan yang diterima oleh karyawan dan wisatawan atas seluruh variabel berkisar antara 3 hingga 4 . Kabupaten Kediri dapat diketahui bahwa Transglobal Leadership, Quality of Work Life, Keterlibatan Pekerjaan, Organizational Citizenship Behavior, Kinerja Sumber Daya Manusia, Pemasaran Bertanggungjawab, dan Daya Saing Pariwisata Berkelanjutan berada pada kuadran II (Keep up the Good Work). Hal ini menunjukkan bahwa harapan dan kenyatan yang diterima karyawan dan wisatawan atas seluruh variabel samasama tinggi. Secara spesifik, nilai harapan dan kenyataan yang diterima oleh karyawan dan wisatawan atas seluruh variabel berkisar antara 3 hingga 4 . Kota Kediri Berdasarkan diagram tersebut dapat diketahui bahwa Transglobal Leadership, Quality of Work Life, Keterlibatan Pekerjaan, Organizational Citizenship Behavior, Kinerja Sumber Daya Manusia, Pemasaran Bertanggungjawab, dan Daya Saing Pariwisata Berkelanjutan berada pada kuadran II (Keep up the Good Work). Hal ini menunjukkan bahwa harapan dan kenyatan yang diterima karyawan dan wisatawan atas seluruh variabel samasama tinggi. Secara spesifik, nilai harapan dan kenyataan yang diterima oleh karyawan dan wisatawan atas seluruh variabel berkisar antara 3 hingga 4 .

Kabupaten Blitar dapat diketahui bahwa Transglobal Leadership, Quality of Work Life, Keterlibatan Pekerjaan, Organizational Citizenship Behavior , Kinerja Sumber Daya Manusia, Pemasaran Bertanggungjawab, dan Daya Saing Pariwisata Berkelanjutan berada pada kuadran II (Keep up the Good Work). Hal ini menunjukkan bahwa harapan dan kenyatan yang diterima karyawan dan wisatawan atas seluruh variabel samasama tinggi. Secara spesifik, nilai harapan dan kenyataan yang diterima oleh karyawan dan wisatawan atas seluruh variabel berkisar antara 3 hingga 4 . Kota

\section{SIMPULAN}

Berdasarkan hasil penelitian dapat disimpulkan bahwa Importance Performance Analysis (IPA) untuk mendapatkan gambaran: tingkat kepuasan dan kepentingan SDM UMKM sektor pariwisata di Jawa Timur. Setiap Importance Performance Analysis (IPA) menghasilkan keunggulan masing-masing variabel yang menentukan tingkat validitas rekomendasi alternatif. Penelitian ini penting dilakukan karena memberikan kontribusi banyak pihak, yaitu menghasilkan model strategi pemasaran yang bertanggung jawab (responsibility marketing) yang dapat digunakan oleh pemerintah Jawa Timur dalam rangka meningkatkan kebijakan untuk mewujudkan daya saing berkelanjutan pariwisata (pariwisata berkelanjutan; pemasaran yang bertanggung jawab (responsibility marketing) menyediakan kerangka kerja koordinasi yang komprehensif sehingga diharapkan para pemangku kepentingan akan mendapatkan model strategi pemasaran yang bertanggung jawab untuk mengembangkan destinasi pariwisata berkelanjutan; dan penelitian ini juga merupakan alat dalam pengembangan ilmiah, khususnya di bidang strategi SDM, strategi pemasaran dan pemasaran pariwisata yang bertanggung jawab.

\section{DAFTAR PUSTAKA}

Alotaibi, A. G. (2001). Antecedents of organizational citizenship behavior: A study of public personnel in Kuwait. Public Personnel Management, 30(3), 363-376.

Bernadin, H. J., \& Russel, J. E. (1993). Human Resource Resource 
Management: An experimental Approach: MccGraw-Hill. Inc.

Dewi, R. (2011). Pengembangan Konsep Pemukiman Berkelanjutan (Studi Kasus di Pemukiman Kumuh Kecamatan Banda Sakti Kota Lhokseumawe).

Hayward, S. (2010). Engaging employees through whole leadership. Strategic HR Review.

Hermawati, A., \& Mas, N. (2016). Transglobal Leadership, Quality of Work Life, and Employee Performance in Cooperatives in East Java, Indonesia. International Journal of Business Management , 1(1), 1-8. https://sciarena.com/storage/models/a rticle/qOKiof9QiZupkCkIfu2K1nuqi kx5KBxRO2OE9g86ci4U505bsgLz1 80rjlYt/transglobal-leadershipquality-of-work-life-and-employeeperformance-in-cooperatives-in-eastjava-.pdf

Holt, K., \& Seki, K. (2012). Global leadership: A developmental shift for everyone. Industrial and Organizational Psychology, 5(2), 196-215.

Kemenparekraf. (2016). data-kunjunganwisatawan-mancanegara-bulanantahun-2016

www.kemenparekraf.go.id. https://www.kemenparekraf.go.id/pos t/data-kunjungan-wisatawanmancanegara-bulanan-tahun-2016

Meler, M., \& Ham, M. (2012). Green marketing for green tourism. Faculty of Tourism and Hospitality Management in Opatija. Biennial International Congress. Tourism \& Hospitality Industry, 130.

Porter, L. W., \& Lawler, E. E. (1968). Managerial attitudes and performance.

Robbins, S. P., \& Judge, T. A. (2006). Perilaku organisasi. Edisi Kesepuluh. Jakarta: PT Indeks Kelompok Gramedia.

Sarkar, N., Ghosh, S. K., Bannerjee, S., \& Aikat, K. (2012). Bioethanol production from agricultural wastes: an overview. Renewable Energy, 37(1), 19-27.

Soumendu, B., \& Arup, V. (2007). Psychological climate and individual performance in India: test of a mediated model. Employee Relations, 29(6), 664-676. https://doi.org/10.1108/01425450710 826131

Statistik, B. P. (2018). statistik-indonesia$2018 @$ @ww.bps.go.id. 2018. https://www.bps.go.id/publication/20 18/07/03/5a963c1ea9b0fed6497d084 5/statistik-indonesia-2018.html

Suci, R. P., Hermawati, A., \& Isma, Y. El. (2017). Strategi Pengelolaan SDM Berbasis Transglobal Leadership Pada UMKM Malang Raya. Seminar Nasional Hasil Penelitian Universitas Kanjuruhan Malang, 577-588.

Suhermin. (2015). Effect of Work Stress, Job Satisfaction, Empowerment of Psychology of Intention to Stay. International Journal of Management Sciences, 5(3), 206-212.

Tett, R. P., \& Meyer, J. P. (1993). Job satisfaction, organizational commitment, turnover intention, and turnover: path analyses based on meta-analytic findings. Personnel Psychology, 46(2), 259-293.

UNWTO, J. (2016). World Tourism Barometer. Vol. 14. 